\title{
Perbedaan Perilaku Asertif Ditinjau dari Tipe Kepribadian Menurut Carl Gustav Jung (Studi Komparatif Pada Mahasiswa Organisator Universitas Islam Negeri Antasari Banjarmasin)
}

\author{
Pahmiah, Mubarak, dan Mahdia Fadhila \\ Universitas Islam Negeri Antasari Banjarmasin
}

\begin{abstract}
The purpose of this study was to decide whether there are differences in assertive behavior between extrovert and introvert personality among student organizers of State Islamic University Antasari Banjarmasin. The type of research used is a comparative approach. The sampling method used improbability sampling. The population in this study were students who were members of the Student Executive Board at the Faculty level at State Islamic University Antasari Banjarmasin with a total population of 152 people while the sample used was 60 people. The measuring instrument used to measure assertive behavior constructed by the researcher from the aspects of assertive behavior according to Alberti and Emmons, while personality was also constructed by the researcher by identifying the general characteristics of each of the extrovert and introvert personality types. The results obtained from data analysis show that the sig. (2-tailed) $0.001<0.05$, which means that there is a significant difference in assertive behavior among student organizers who have an extrovert personality type and an introvert personality type.
\end{abstract}

Keywords: assertive behavior; extrovert; introvert; student organizer.

\begin{abstract}
Abstrak
Tujuan penelitian ini dilakukan ialah untuk mengetahui apakah terdapat perbedaan perilaku asertif antara kepribadian ekstrovert dan introvert pada mahasiswa organisator UIN Antasari Banjarmasin. Jenis Penelitian yang digunakan adalah pendekatan komparatif. Metode pengambilan sampel menggunakan nonprobability sampling. Populasi dalam penelitian ini adalah mahasiswa yang menjadi anggota Dewan Eksekutif Mahasiswa tingkat Fakultas se-UIN Antasari Banjarmasin dengan jumlah populasi sebanyak 152 orang sedangkan sampel yang digunakan sebanyak 60 orang. Alat ukur yang digunakan untuk mengukur perilaku asertif dikonstruk oleh peneliti dari aspek-aspek perilaku asertif menurut Alberti dan Emmons, sedangkan kepribadian juga dikonstruk oleh peneliti dengan mengidentifikasi karakteristik umum masing-masing tipe kepribadian ekstrovert dan introvert. Hasil yang diperoleh dari analisa data menunjukkan bahwa nilai sig. (2-tailed) 0,001 < 0,05 yang artinya terdapat perbedaan yang signifikan perilaku asertif pada mahasiswa organisator yang memiliki tipe kepribadian ekstrovert dan tipe kepribadian introvert.
\end{abstract}

Kata kunci: perilaku asertif; ekstrovert; introvert; mahasiswa organisator. 
Mahasiswa yang bersosialisasi akan selalau berhubungan dengan sesama karena mahasiswa harus mampu membuktikan dirinya dapat bersosialisasi dengan orang lain. Sama halnya dengan mahasiswa yang berperan dalam dunia kampus harus menjaga sikap yang mandiri, positif, inovatif, kritis, dan dewasa dalam berpikir dan berperilaku.

Perilaku kritis mahasiswa dalam mengungkapkan pendapat dan tuntutan mereka biasanya tidak sadar akan porsi mereka. Seringkali kita menemui perilaku mahasiswa saat terjadinya suatu konfik, misalnya pada saat mereka tidak menyetujui suatu keputusan yang telah ditetapkan oleh kampusnya. Di antara mereka ada yang mengungkapkan aspirasinya dengan perilaku yang kurang asertif misalnya memprovokasi pihak lain, menjatuhkan nama baik orang lain, dan lain sebagainya. Seharusnya mahasiswa harus memahami situasi yang terjadi dan berusaha untuk berdiskusi dengan baik dan etis dengan pihak universitas sehingga tidak terjadi kesalahpahaman. Sayangnya yang terjadi saat ini mahasiswa bersikap anarkis tanpa bersikap asertif.

Agar mempermudah mahasiswa dalam menjalin hubungan dan berinteraksi dengan lingkungan sekitarnya maupun lingkungan luarnya, mahasiswa perlu memiliki perilaku asertif sehingga proses komunikasi dapat berlangsung secara efektif (Anfajaya \& Indrawati, 2016). Perilaku asertif mengacu pada perilaku yang mampu mengekspresikan perasaan dan pikiran seseorang tanpa rasa cemas, serta menghormati orang lain dalam setiap interaksi yang dilakukan (Alberti \& Emmons, 2017).

Mahasiswa yang ikut organisasi biasanya menguasai public speaking yang baik, mempunyai relasi pertemanan akan tetapi fakta di lapangan menyatakan bahwa mahasiswa yang mengikuti organisasi ada mahasiswa yang hanya mencantumkan namanya saja tanpa ikut terlibat dalam diskusi, hal ini dikarenakan kurangnya perilaku asertif yang dimiliki oleh mahasiswa seperti kurang tegas dalam berkomunikasi dengan orang lain serta malu mengungkapkan pendapat dalam diskusi.

Kenyataan di lapangan menunjukkan bahwa masih ada mahasiswa yang mengikuti organisasi kurang memiliki perilaku asertif. Seperti yang diungkapkan oleh NS bahwa pada saat rapat berlangsung ketika ia ingin mengemukan pendapat ia sering merasa takut dan kurang nyaman karena takut perkataannya dapat menyinggung teman yang lain. Padahal rapat 
itu sendiri memiliki tujuan untuk memperbaiki beberapa kinerja dalam organisasi agar lebih baik kedepannya. Hal lain juga disampaikan oleh MB bahwa ia sering mengemukakan pendapat yang ia miliki dan jika ada teman yang lain yang tidak setuju dengan pendapatnya ia akan menanyakan bagaimana solusi yang hendak diambil untuk jalan keluar dari masalah yang ada diorganisasinya, orang yang mengemukakan pendapat dalam organisasi biasanya orangnya selalu itu-itu aja sementara yang lain hanya diam mendengarkan saja. Hal serupa diungkapkan oleh MS bahwa ketika sedang berdiskusi, tidak semua temannya dalam organisasi mampu menyampaikan pendapat. Sebagian mengungkapkan pendapat sementara yang lainnya hanya memilih untuk diam saja. Dari hasil wawancara kepada para responden membuktikan bahwa mahasiswa yang mengikuti organisasi masih kurang dalam berperilaku asertif.

Hasil wawancara tersebut juga dibuktikan dalam hasil observasi yang dilakukan oleh peneliti yang berperan sebagai partisipan pada saat studi pendahuluan. Dari organisasi yang diobservasi oleh peneliti diketahui bahwa ada mahasiswa yang ikut organisasi lebih memilih bersikap diam saja ketika proses diskusi untuk kegiatan berlangsung dalam sebuah organisasi yang diikutinya. Selain itu, peneliti juga menemukan bahwa juga ada mahasiswa yang lain yang dapat mengemukakan pendapat dengan baik tanpa menyinggung siapapun dan juga mampu menghormati hak dan kewajiban orang yang ia tegur dengan baik.

Manusia merupakan ciptaan Allah yang paling sempurna, dalam menjalani kehidupan manusia dianjurkan untuk berperilaku asertif. Seperti halnya pengertian dari asertif merupakan perilaku individu yang mampu mengekspresikan emosi secara tepat dan memiliki rasa percaya diri dalam komunikasi yang relatif terbuka. Tindakan asertif tidak dalam bentuk menganggu kebebasan orang lain juga tidak menggunakan kekerasan, karena suatu penegasan hanya dilakukan dengan jujur ketika mengutarakan pendapat serta tidak merugikan dan menentang hak dan moral. Di dalam agama Islam, kita telah diajarkan agar mampu berperilaku tegas terutama ketika menerapkan berbuat kebaikan, amar ma'ruf nahi mungkar, mencegah pada kemungkaran, dan juga selalu berbicara jujur serta satun kepada sesama manusia (Puspa, 2019). Yang mana hal tersebut sudah ditegaskan dalam surat Al-Imran ayat 159: 


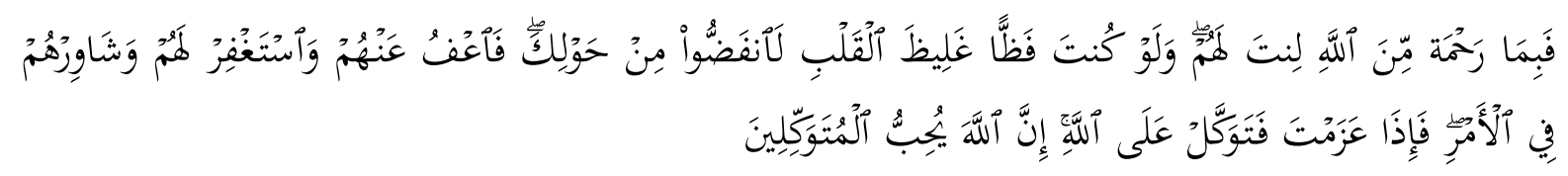

Maka disebabkan rahmat dari Allah-lah kamu berlaku lemah lembut terhadap mereka. Sekiranya kamu bersikap keras lagi berhati kasar, tentulah mereka menjauhkan diri dari sekelilingmu. Karena itu maafkanlah mereka, mohonkanlah ampun bagi mereka, dan bermusyawaratlah dengan mereka dalam urusan itu. Kemudian apabila kamu telah membulatkan tekad, maka bertawakkallah kepada Allah. Sesungguhnya Allah menyukai orang-orang yang bertawakkal kepada-Nya.

Pada surat Al-Imran ayat 159 di atas menegaskan bahwa mahasiswa harus bersikap tegas dalam hal kebenaran, berkata jujur, terbuka dan harus didasari dengan kasih sayang yang dalam hal ini bukan sekedar hanya saling tegur sapa, namun juga harus menyiarkan amanat Allah dalam hal keadilan dan kesamarataan sosial diantara lingkungan manapun khususnya dalam organisasi, perlu ditanamkan perilaku sertif dalam diri mahasiswa yang mengikuti organisasi dengan berpedoman pada tuntutan-tuntutan Islam yang sudah dijelaskan oleh peneliti sebelumnya. Hal tersebut berarti dalam kehidupan berorganisasi mahasiswa perlu memiliki perilaku asertif sehingga dapat berkomunikasi dengan tepat dan tegas namun tidak mengabaikan hak dan menyakiti orang lain.

Dalam lingkungan organisasi biasanya seringkali mahasiswa secara tidak sadar jika sedang dalam keadaan emosi yang membuat mulut bisa berkata kasar dan menyakiti hati orang lain. Allah melarang umat muslim menyakiti hati orang lain dengan mengucapkan kata-kata kasar yang dapat mengakibatkan pertengkaran dan permusuhan.

Perilaku asertif yang ada dalam diri seseorang tidak muncul dengan sendirinya melainkan disebabkan oleh beberapa faktor, salah satu faktor yang mempengaruhi terbentuknya perilaku asertif adalah kepribadian. Kepribadian tidak akan pernah lepas dari dalam diri manusia (Kurniawan, 2016). Kepribadian merupakan keseluruhan perilaku dari seorang individu dengan sistem kecenderung tertentu yang berinteraksi dengan serangkaian instruksi (2015).

Carl Gustav Jung menyampaikan mengenai tolak ukur dan konsep utama dalam melaksanakan analisis psikologi kepada seseorang yaitu dengan meneliti sifat individual yang ada dalam diri mereka. Dalam Naisaban, Jung mengungkapkan bahwa tipe kepribadian 
manusia ada dua, yaitu ekstrovert dan introvert (Kurniawan, 2016). Jika individu memiliki orientasi objektif maka individu tersebut memiliki kecenderungan pada tipe kepribadian ekstrovert. Sebaliknya jika individu tersebut memiliki kecenderungan kepribadian introvert maka orientasi faktor subjektiflah yang ada dalam dirinya atau faktor yang berasal dari dunia batinnya sendiri (Azizah, 2016). Sehingga penelitian ini memiliki tujuan untuk mengetahui apakah ada perbedaan mahasiswa organisator yang memiliki tipe kepribadian ekstrovert dan introvert dalam berperilaku asertif.

Berdasarkan pendahuluan yang telah dilakukan, peneliti sangat tertarik dalam mengkaji penelitiannya mengenai pemaparan perbedaan perilaku asertif ditinjau dari tipe kepribadian menurut Carl Gustav Jung pada mahasiswa organisator, kategori perilaku asertif pada mahasiswa organisator, kecenderungan tipe kepibadian pada mahasiswa organisator, pengaruh perilaku asertif terhadap tipe kepribadian, serta kecenderungan perilaku asertif yang dilakukan mahasiswa organisator.

\section{Metode}

Penelitian ini menggunakan metode kuantitatif dengan jenis penelitian komparatif, yaitu metode penelitian yang digunakan dalam penelitian untuk mengetahui apakah terdapat perbedaaan atau tidak pada variable yang diteliti. Subjek dalam penelitian ini adalah anggota DEMAF UIN Antasari Banjarmasin periode 2019-2020 dengan jumlah populasi sebanyak 152 responden dan data yang digunakan sebagai sampel penelitian sebanyak 60 responden. Teknik yang digunakan pada pengambilan sampel adalah teknik secara nonprobability sampling dengan teknik kouta sampling adalah penentuan jumlah kouta yang ditetapkan oleh peneliti dan teknik porpusive sampling, teknik pengambilan sampel dengan menggunakan karakterisik pada penentuan sampelnya serta tidak memberikan peluang yang sama(Sugiyono, 2006), peneliti memilih mengambil double sampling sekaligus dengan tujuan untuk melengkapi jumlah data apabila data yang tidak termasuk dalam teknik sampel yang pertama atau untuk menyeleksi mengenai kebenaran data dari sampel yang pertama.

Teknik pengumpulan data mengunakan 2 skala psikologi yaitu skala perilaku asertif dan skala tipe kepribadian. Kedua skala ini di serahkan kepada 3 orang profesional judgment untuk dilakukan judgment agar tidak termuat unsur subjektif. Skala perilaku asertif yang 
dikonstruk oleh peneliti menurut Alberti dan Emmons dengan aspek mempromosikan kesetaraan hubungan, bertindak menurut kepentingan sendiri, mampu membela diri sendiri, mengekspresikan perasaan secara jujur dan nyaman, mempertahankan hak pribadi, serta menghargai hal-hak orang lain (Alberti \& Emmons, 2017). Sedangkan skala kepribadian juga dikonstruk oleh peneliti dengan mengidentifikasi karakteristik umum masing-masing tipe kepribadian ekstrovert dan introvert menurut Carl Gustav Jung yaitu pengalaman yang palng banyak mempengaruhi diri, pemusatan perhatian, pertimbangan dan kedalaman berpikir, interaksi dengan prang lain atau hubungan sosial, adaptasi dengan lingkungan, habit (kebiasaan) perilaku, penerimaan sosial serta kepedulian terhadap penderitaan. Kedua skala ini memiliki nilai Cronbach's Alpha sebesar 0,766 > 0,60, sedangkan skala kepribadian memiliki nilai Cronbach's Alpha sebesar 0,711 yang berarti item-item dari variabel kedua skala tersebut reliabel atau dapat digunakan sebagai alat pengumpul data penelitian. Selanjutnya skala asertif memiliki item yang dapat digunakan untuk penelitian sebanyak 30 item dengan rincian 17 item favorable dan 13 item unfavorable sedangkan untuk skala kepribadian mempunyai 26 item berpasangan yang dapat digunakan untuk kepentingan penelitian. Penelitian ini juga menggunakan metode wawancara dan observasi pada studi pendahuluan serta berbagai literatur yang relevan. Sebelum disebarkan dengan sampel yang telah ditentukan, peneliti terlebih dahulu melakukan uji coba terhadap kedua skala dengan 60 orang responden yang memiliki kesamaan kriteria dengan sampel penelitian yaitu mahasiswa yang mengikuti organisasi di kampusnya.

Sebelum analisis data dilakukan, terlebih dahulu melakukan uji normalitas dan uji homogenitas data penelitian. Selanjutnya peneliti menggunakan analisis data kategorisasi, uji regresi sederhana, uji independent simple t-test serta sumbangsi efektif dengan bantuan IBM SPSS 21.0 Software.

\section{H a s i 1}

\section{Uji Normalitas dan Homogenitas Data}

Berikut ini hasil perhitungan uji normalitas data yang telah dilakukan dengan menggunakan SPSS 21.0: 
Tabel 1

Hasil Uji Normalitas Data

\begin{tabular}{lcccc}
\hline & Kepribadian & & Shapiro-Wik & \\
& & Statistic & Df & Sig. \\
\hline \multirow{2}{*}{ Asertif } & Rendah &, 962 & 33 &, $\mathbf{2 9 3}$ \\
& Tinggi &, 946 & 27 & $\mathbf{1 6 9}$ \\
\hline
\end{tabular}

Pada tabel 1 diatas, dapat diketahui bahwa variabel ekstrovert memiliki nilai sig. 0,293 > 0,05 yang artinya data tersebut diasumsikan berdistribusi normal. Sedangkan pada variabel introvert memiliki nilai Sig. 0,169 > 0,05 yang berarti data tersebut juga berdistribusi normal.

Selanjutnya untuk hasil uji homogenitas dapat dilihat dibawah ini:

Tabel 2

Hasil Uji Homogenitas

Test of Jomogeneity of Variances

Asertif

\begin{tabular}{cccc}
\hline Levene Statistic & $\mathrm{dfl}$ & $\mathrm{df2}$ & Sig \\
1,906 & 1 & 58 & $\mathbf{1 7 3}$ \\
\hline
\end{tabular}

Dari tabel 2 menunjukkan nilai sig. 0,173 > 0,05 yang berarti bahwa dua variabel tersebut memiliki varian yang sama atau homogen.

Analisis Deskriptif Penelitian

Sebelum analisis data dilakukan, peneliti mengambil data dengan dengan menggunakan kuesioner secara langsung yang disebarkan secara daring melalui Google form kepada responden yang sesuai dengan kriteria pada penelitian. Pengambilan data dilakukan selama 20 hari, yaitu dari tanggal 02 Desember 2020 sampai dengan 22 Desember 2020. Deskripsi Responden Penelitian dapat dilihat pada tabel 3 berikut ini:

\section{Tabel 3}

Jumlah Responden Penelitian

\begin{tabular}{cccc}
\hline No. & Asal Organisasi & Frekuensi & Presentase \\
\hline 1. & Dewan Eksekutif Mahasiswa Fakultas Ushuluddin dan & 16 & $\mathbf{2 6 , 7 \%}$ \\
Humaniora & & \\
2. & Dewan Eksekutif Mahasiswa Fakultas Tarbiyah dan & 15 & $\mathbf{2 5 \%}$ \\
$\quad$ Keguruan & 9 & $\mathbf{1 5 \%}$ \\
3. & Dewan Eksekutif Mahasiswa Fakultas Syariah & 10 & $\mathbf{1 6 , 7 \%}$ \\
4. & Dewan Eksekutif Mahasiswa Fakultas Ekonomi dan \\
& Bisnis Islam & &
\end{tabular}


5. Dewan Eksekutif Mahasiswa Fakultas Dakwah dan Ilmu

10

$16,7 \%$ Komunikasi

\section{Total}

60 $100 \%$

Analisis deskriptif digunakan untuk menggambarkan hasil penelitian yang dilakukan secara umum agar dapat mengetahui kategorisasi tingkatan pada subjek penelitian. Kategorisasi merupakan pemberian interpretasi terhadap skor skala yang bersangkutan. Pengkategorian skala menggunakan bantuan Software SPSS 21.0 for Windows. Perhitungan untuk perilaku asertif terdiri dari dua jenjang dengan rumus (Azwar, 2013):

\section{Tabel 4}

Pengelompokkan Perilaku Asertif

\begin{tabular}{cccc}
\hline Kategori & Skor & Frekuensi & Presentase \\
\hline Rendah & $X<88,38$ & 32 & $\mathbf{5 3 , 3 \%}$ \\
Tinggi & $X \geq 88,38$ & 28 & $\mathbf{4 6 , 7 \%}$ \\
Total & & $\mathbf{6 0}$ & $\mathbf{1 0 0 \%}$ \\
\hline
\end{tabular}

Berdasarkan tabel 4 kategorisasi dua jenjang di atas dan hasil perhitungan menggunakan bantuan Software SPSS 21.0 for Windows besar $\mu$ untuk perilaku asertif adalah 88,38 . Selanjutnya diketahui bahwa perilaku asertif pada mahasiswa organisator UIN Antasari Banjarmasin sebanyak 32 responden (53,3\%) memiliki perilaku asertif yang rendah, sedangkan sebanyak 28 responden (46,7\%) memiliki perilaku asertif yang tinggi. Hal ini berarti dalam berpeerilaku asertif mahasiswa organisator UIN Antasari lebih dominan berada pada tingkat yang rendah. Agar lebih jelas dapat dilihat pada gambar 1 berikut ini:

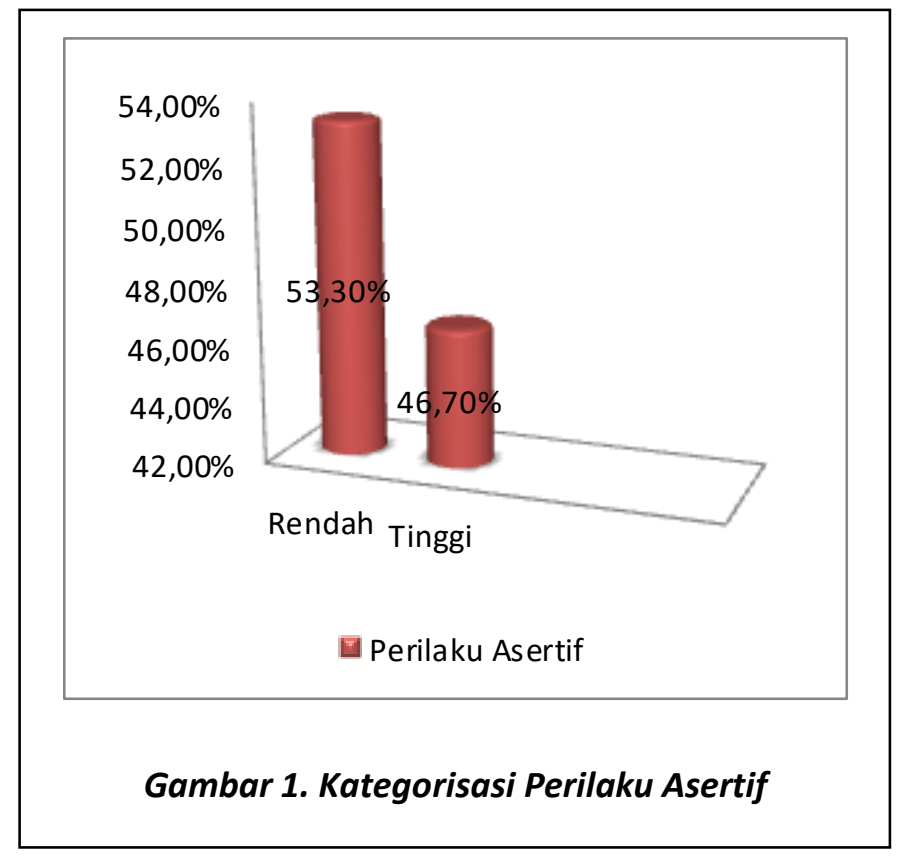


Selanjutnya untuk mengetahui berapa banyak responden yang memiliki kecenderungan tipe kepribadian ekstrovert dan introvert, dapat dilihat pada tabel distribusi frekuensi dibawah ini:

Tabel 5

Distribusi Frekuensi Tipe Kepribadian

\begin{tabular}{ccc}
\hline Tipe Kepribadian & Frekuensi & Presentase \\
\hline Ekstrovert & 33 & $\mathbf{5 5 \%}$ \\
Introvert & 27 & $\mathbf{4 5 \%}$ \\
Total & $\mathbf{6 0}$ & $\mathbf{1 0 0} \%$ \\
\hline
\end{tabular}

Pengelompokkan tipe kepribadian dengan cara menghitung banyaknya jumlah pilihan subjek pada masing-masing kecenderungan tipe kepribadian, sehingga diketahui bahwa tipe kepribadian mahasiswa organisator UIN Antasari Banjarmasin dari jumlah responden 60 sebanyak 33 responden atau 55\% memiliki kecenderungan kepribadian ekstrovert dan sebanyak $45 \%$ atau 27 responden memiliki kecenderungan kepribadian introvert. Untuk lebih jelasnya dapat dilihat dalam gambar, sebagai berikut:

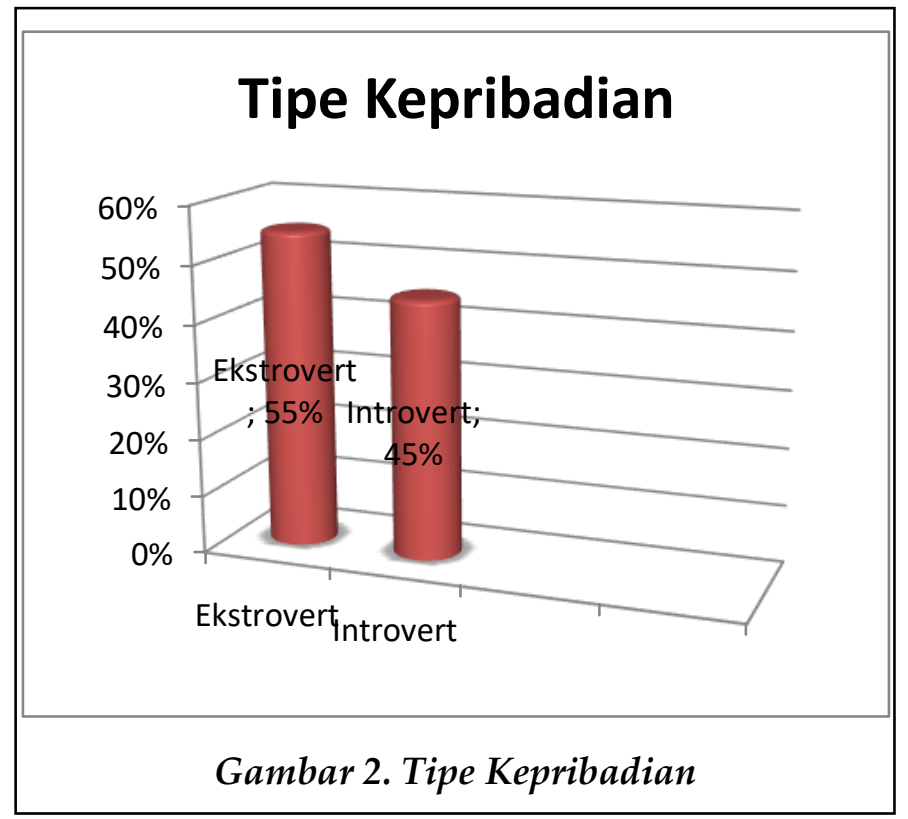


Selanjurnya untuk melihat seberapa besar pengaruh variabel perilaku asertif dengan tipe kepribadian, maka dapat dilihat pada tabel di bawah ini:

Tabel 6

Hasil Uji Regresi

\begin{tabular}{ccccc}
\hline Model & $R$ & $R$ Square & $\begin{array}{c}\text { Adjusted } R \\
\text { Square }\end{array}$ & Std. Error of the Estimate \\
\hline 1 &, $411^{\mathrm{a}}$ & 169 &, 155 & 8,189 \\
\hline
\end{tabular}

Dari tabel 6 diketahui bahwa besar nilai hubungan atau kolerasi yaitu sebesar 0,411 dan nilai koefisien determinasi ( $R$ Square) sebesar 0,169 yang berarti bahwa pengaruh perilaku asertif terhadap tipe kepribadian adalah sebesar $16,9 \%$.

Berikut ini hasil perhitungan dari uji Independent Simpel T-test:

Tabel 7

Hasil Uji Independet Simpel T-Test

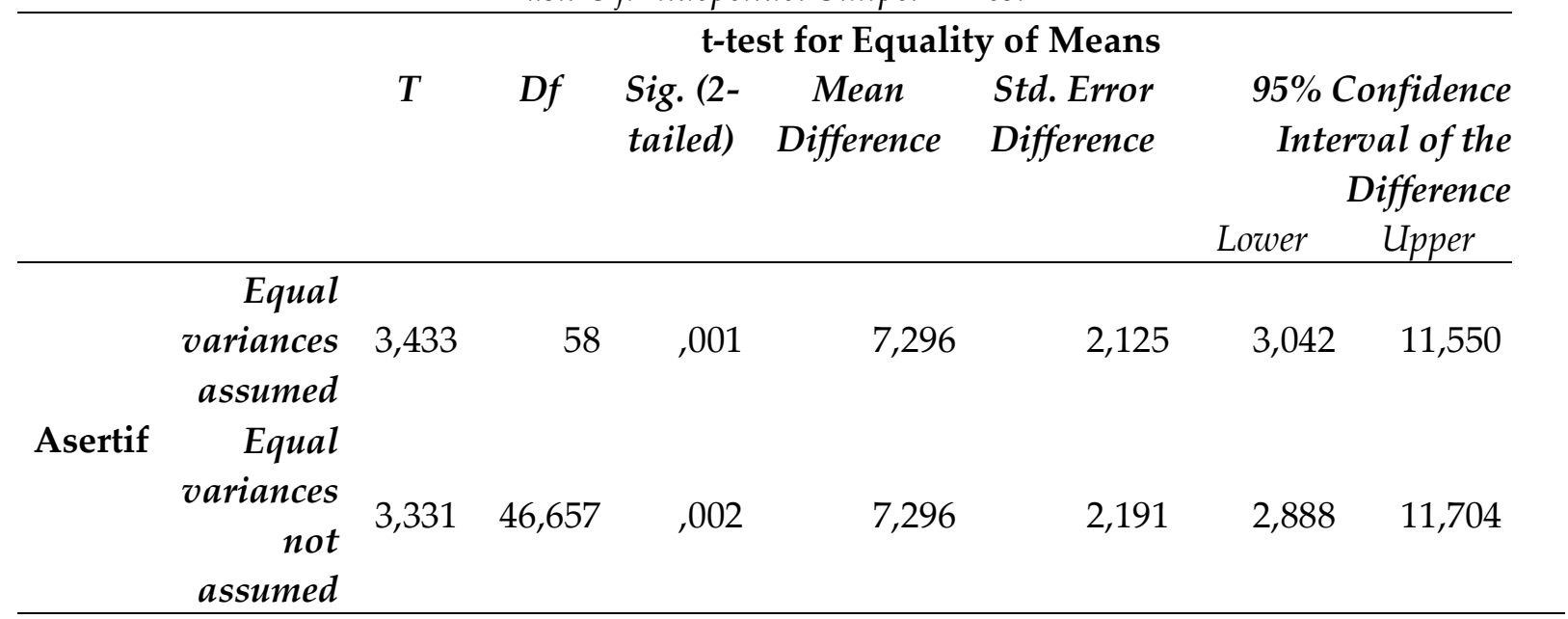

Tabel 4 menunjukkan diketahui bahwa terdapat nilai sig. (2-tailed) 0,001<0,05 yang artinya bahwa maka Ho ditolak dan Ha diterima. Sehingga dapat disimpulkan bahwa terdapat perbedaan yang signifikan perilaku asertif pada mahasiswa organisatoris yang memiliki tipe kepribadian ekstrovert dan tipe kepribadian introvert.

Untuk mengetahui perbedaan perilaku asertif ditinjau dari tipe kepribadian menurut Carl Gustav Jung pada mahasiswa organisator UIN Antasari Banjarmasin adalah rata-rata (mean diference) sebesar 7,296 dan perbedaan berkisar antara 3,042 sampai 11,550 (lihat lower dan upper), karena nilai rerata berbentuk positif, berarti kelompok pertama (kepribadian ekstrovert) 
memiliki mean lebih besar dari kelompok kedua (kepribadian introvert). Maka dapat disimpulkan bahwa kecenderungan kepribadian ekstrovert memiliki perilaku asertif yang lebih tinggi dibanding kecenderungan kepribadian introvert.

Selanjutnya untuk menghitung besaran sumbangan efektif per aspek dari aspek skala perilaku asertif pada mahasiswa organisator dengan hasil data pada tabel 8 berikut ini:

Tabel 8

Koefisien Nilai Perhitungan Sumbangsi Tiap Aspek Perilaku Asertif Terhadap Variabel Perilaku

\begin{tabular}{|c|c|c|c|c|c|}
\hline No. & Aspek & B & Cross-product & Regresi & $\begin{array}{c}\text { Sumb. } \\
\text { Efektif Total }\end{array}$ \\
\hline 1. & $\begin{array}{l}\text { Mempromosikan kesetaraan } \\
\text { dalam hubungan manusia. }\end{array}$ & 1 & 607,667 & $\begin{array}{c}4938,58 \\
3\end{array}$ & $100 \%$ \\
\hline 2. & $\begin{array}{l}\text { Bertindak menurut } \\
\text { kepentingan sendiri }\end{array}$ & 1 & 1545,333 & & \\
\hline 3. & Membela diri sendiri & 1 & 890,667 & & \\
\hline 4. & $\begin{array}{l}\text { Mengekspresikan perasaan } \\
\text { secara jujur dan nyaman }\end{array}$ & 1 & 413,583 & & \\
\hline 5. & $\begin{array}{l}\text { Mempertahankan hak-hak } \\
\text { Pribadi }\end{array}$ & 1 & 648,083 & & \\
\hline 6. & $\begin{array}{l}\text { Menghargai hak-hak orang } \\
\text { Lain }\end{array}$ & 1 & 833,250 & & \\
\hline
\end{tabular}

Setelah nilai koefisien telah diketahui maka untuk mengetahui persentase (\%) sumbangsih pada tiap-tiap aspek maka angka-angka diatas dimasukkan ke dalam rumus di bawah ini:

$$
S E_{X_{i}}=\left|\frac{b_{X_{i}} \cdot C P_{X i}}{\text { Regression }}\right| \mathrm{X} \mathrm{R}^{2}
$$

(1) rumus sumbangsih efektif

Berdasarkan hasil perhitungan dengan menggunakan rumus di atas dapat diketahui bahwa sumbangsih mahasiswa organisator pada perilaku asertif yang terdiri dari aspek mempromosikan kesetaraan hubungan memberikan sumbangsih pada perilaku asertif sebesar $12,3 \%$, bertindak menurut kepentingan sendiri sebesar 31,2\%, mampu membela diri sendiri sebesar 18\%, mengekspresikan perasaan secara jujur dan nyaman sebesar 8,4\%, 
mempertahankan hak pribadi sebesar 13,1\%, serta pada aspek menghargai hal-hak orang lain sebesar 16,9\%. Hal ini berarti mahasiswa organisator akan berperilaku asertif ketika hal tersebut berkaitan dengan bertindak menurut kepentingan sendiri. Dapat dilihat pada gambar di bawah ini:

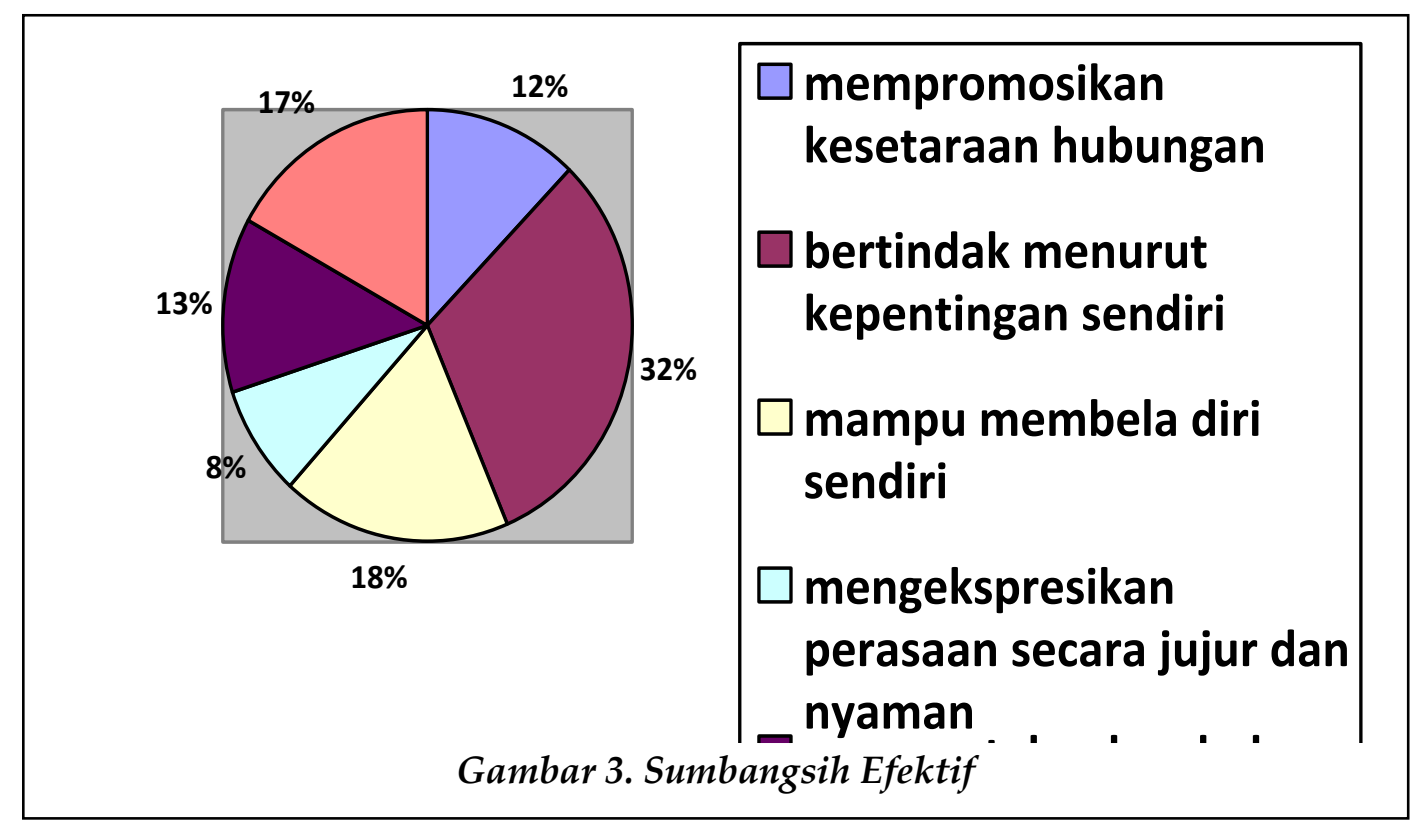

\section{Pembahasan}

Linda Adams dan Elinor Lenz mendefinisikan perilaku asertif artinya memahami hal yang ingin dilakukan, menjelaskan dan bekerja sama dengan orang lain dengan caranya sendiri agar terpenuhinya kebutuhan sendiri juga dengan tetap menghormati individu lain (Adams \& Lens, 1995). Perilaku asertif adalah hal yang penting dalam kehidupan organisasi karena dengan berperilaku asertif kita dapat mengkomunikasikan apa yang kita rasakan dan ingin kita ungkapkan tanpa harus merendahkan orang lain.

Pada hasil analisis penelitian di atas diketahui bahwa kategori perilaku asertif pada mahasiswa organisator UIN Antasari Banjarmasin berada pada persentase yang rendah sebesar 53,3\%. Karlina Dewi berpendapat bahwa mahasiswa yang memiliki perilaku asertif rendah biasanya berperilaku kurang berani mengungkapkan pendapat, kurang percaya diri, dan tidak dapat mempertahankan hak pribadi dengan baik (Dewi, 2017). Selanjutnya, hasil penelitian juga menunjukkan bahwa mahasiswa memiliki perilaku asertif yang tinggi (46,7\%), Marlise 
Butar Butar dalam penelitiannya mengungkapkan mengenai mahasiswa yang mempunyai perilaku asertif yang tinggi maka mahasiswa akan dapat mengkomunikasikan keinginan kebutuhan dan opini kepada orang lain dengan cara terbuka dan jujur tanpa menyakiti orang lain (Butar, 2017). Hal ini bermakna bahwa dengan adanya perilaku asertif yang tinggi, mahasiswa akan lebih mampu menjaga dirinya, lebih menghargai dirinya sehingga tidak melakukan perilaku menyimpang dan dapat mengontrol dirinya saat berperilaku dalam kegiatan berorganisasi.

Menurut Priambodo dan Sarwono dalam skripsi Wahidiyanti, mahasiswa yang mengikuti organisasi memiliki ciri-ciri, yaitu individu yang sering menghabiskan waktu dengan berbagai kegiatan kemahasiswaan, cenderung sering duduk-duduk dan berbincangbincang di ruangan atau kantor organisasi kemahasiswaan yang diikuti, cenderung mempunyai wawasan yang luas, pemikiran yang kritis, lebih peka dan lebih kritis mengenai perkembangan dunia luar maupun tentang hal-hal yang terjadi di seputar kampus, cenderung mempunyai kemampuan dalam menyampaikan pendapat dan berkomunikasi secara efektif, serta memiliki keberanian yang dalam mengambil tindakan yang berkaitan dengan mengambil resiko (Wahidiyanti, 2015).

Mahasiswa yang memiliki perilaku asertif dapat bertindak tanpa melanggar hak orang lain, mampu berbicara sesuai dengan apa yang dipikirkan dan dirasakan. Mahasiswa dengan perilaku asertif juga cenderung memiliki pemikiran yang positif sehingga akan mendapatkan manfaat dari berperilaku asertif yaitu dapat meningkatkan harga diri dan kepercayaan diri mahasiswa dalam berorganisasi (Adams \& Lens, 1995). Selain itu menurut Wardhani dalam Zainab, saat mahasiswa berperilaku asertif pada orang lain ia akan terbantu untuk tetap berusaha dalam memahami perasaan, keinginan, dan gagasan diri sendiri sehingga dapat mencapai tujuan yang ia inginkan seperti dapat menyampaikan ide atau gagasannya secara efektif saat diskusi organisasi yang diikutinya (Zainab, 2018).

Di dalam buku Najati memeparkan mengenai Rasulullah saw., memerintahkan agar mengembangkan budaya berani menyampaikan pendapat dikalangan sahabat dan umatnya serta mencegah mereka dari sikap membeo terhadap ide dan perbuatan orang lain tanpa memikirkannya dengan matang terlebih dahulu. Rasulullah saw., mengarahkan dan berpesan 
kepada para sahabat dan umatnya untuk berani mengutarakan pendapat, mengucapkan katakata yang benar serta melarang mereka untuk menjadi orang yang berpikiran sempit, yaitu individu yang tidak memiliki pendirian dan hanya mengikuti apa yang dikatakan oleh orang lain tanpa memikirkannya terlebih dahulu (Najati, 2003).

Gambaran perilaku asertif pada penelitian ini ditinjau melalui aspek-aspek perilaku asertif menurut Alberti dan Emmons adalah mempromosikan kesetaraan hubungan, bertindak menurut kepentingan sendiri, mampu membela diri sendiri, mengekspresikan perasaan secara jujur dan nyaman, mempertahankan hak pribadi, serta menghargai hal-hak orang lain (Alberti \& Emmons, 2017).

Fakta yang di lapangan menyatakan bahwa kecenderungan perilaku asertif pada mahasiswa organiasator yaitu pada aspek mempromosikan kesetaraan hubungan memberikan sumbangsih pada perilaku asertif sebesar 12,3\%, bertindak menurut kepentingan sendiri sebesar 31,2\%, mampu membela diri sendiri sebesar 18\%, mengekspresikan perasaan secara jujur dan nyaman sebesar 8,4\%, mempertahankan hak pribadi sebesar 13,1\%, serta pada aspek menghargai hak-hak orang lain sebesar 16,9\%. Hal ini bermakna bahwa sebagian mahasiswa organisator berperilaku asertif ketika hal tersebut berkaitan dengan bertindak menurut kepentingan diri sendiri, mampu membela diri sendiri, menghargai hak-hak orang lain, mempertahankan hak pribadi, mempromosikan kesetaraan hubungan, serta dalam hal mengekspresikan perasaan secara jujur dan terbuka

Menurut Erlinawati, tinggi rendahnya mahasiswa dalam berperilaku asertif dipengaruhi oleh berbagai faktor (Erlinawati, 2009). Dilihat dari penelitian terdahulu, Antonia Ita Verina menyatakan bahwa perilaku asertif dapat dipengaruhi oleh faktor eksternal dan internal (Verina, 2019). Dalam penelitian Imam Ramdhani menyebutkan jenis kelamin adalah salah satu faktor yang mempengaruhi seseorang dalam berperilaku asertif (Ramdhani W, 2018). Sementara itu Shilmi Khalisah dan Rahmi Lubis menjelaskan bahwa pola asuh juga sebagai hal yang mempengaruhi orang dalam berperilaku asertif (Khalisah \& Lubis, 2016). Anastasia Mira Erlinawati menyebutkan bahwa tipe kepribadian juga dapat mempengaruhi seseorang dalam perilaku asertif (Erlinawati, 2009). 
Sejalan dengan temuan penelitian, diketahui perhitungan pengaruh tipe kepribadian terhadap perilaku asertif pada mahasiswa organisatoris UIN Antasari Banjarmasin sebesar $16,9 \%$, hal ini bermakna tipe kepribadian seseorang menyumbang sebesar 16,9\% dapat mempengaruhinya dalam berperilaku asertif. Akan tetapi, fakta tersebut juga mempunyai makna bahwa ada faktor lain sebesar $83,1 \%$ yang dapat mempengaruhi individu untuk berperilaku asertif khususnya dalam berorganisasi. Namun hal ini tidak menjadi fokus penelitian ini, sehingga dibutuhkan riset lanjutan untuk memastikan faktor lain yang juga berpengaruh pada perilaku asertif seseorang. Pada kesimpulannya dapat diketahui bahwa selain tipe kepribadian yang berasal dari dalam diri individu terdapat faktor eksternal yang berasal dari lingkungan organisasi juga dapat mempengaruhi individu dalam berperilaku asertif.

Carl Gustav Jung berpendapat bahwa kepribadian ialah hal yang memuat mengenai keseluruhan pikiran, perasaan dan tingkah laku, kesadaran dan ketidaksadaran (2015). Ia juga membagi kepribadian manusia menjadi dua tipe, yaitu: ekstrovert dan introvert (Kurniawan, 2016). Berdasarkan pemaparan pada hasil analisis data 33 responden atau 55\% memiliki kecenderungan kepribadian ekstrovert dan sebanyak $45 \%$ atau 27 responden memiliki kecenderungan kepribadian introvert.

Jika merujuk dari hasil analisis data di atas, data tersebut dapat dimaknai bahwa lebih dari separuh (sebanyak 55\%) mahasiswa yang terlibat dalam organisasi memiliki kecenderungan tipe kepribadian ekstrovert. Hal ini berarti individu kecenderungan yang mengarahkan kepribadian ke luar dirinya dibandingkan ke dalam dirinya sendiri, memiliki jiwa sosial yang tinggi, cenderung melakukan tindakan daripada berpikir dan merenung, serta orang yang penuh motif-motif yang dikoordinasi oleh kejadian-kejadian eksternal (Kurniawan, 2016). Sedangkan sebanyak $45 \%$ mahasiswa yang terlibat dalam organisasi lainnya memiliki kecenderungan tipe kepribadian introvert yang berarti individu tersebut lebih mengarah kepada pengalaman subjektif, cenderung menyendiri, menyukai hal yang berkaitan dengan dunia dalam dirinya sehingga privasi hadir sebagai realita yang berasal dari hasil pengamatan, sulit untuk beradaptasi dan kaku dalam pergaulan, pendiam atau tidak ramah, sangat menjaga atau berhati-hati terhadap penderitaan dan miliknya, cenderung diliputi kekhawatiran, mudah 
malu dan canggung, bahkan antisosial. Umumnya individu dengan kepribadian introvert sering introspektif dan sibuk dengan dunia mereka sendiri. Mereka juga mengunci dirinya dari dunia luar dalam memasukkan seorang dari dunia luar, mereka melakukannya sangat selektif dan memakai pandangan subjektif menurut dirinya sendiri (Kurniawan, 2016).

Dari hasil analisis data independepnt simple t-test menggunakan IBM SPSS 21.0 Software diketahui nilai sig. (2-tailed) 0,001 < 0,05 hal ini menunjukkan bahwa terdapat perbedaan perilaku asertif yang signifikan antara mahasiswa organisator yang memiliki kecenderungan tipe kepribadian ekstrovert dan mahasiswa organisator dengan tipe kepribadian introvert yang berarti semakin ekstrovert tipe kepribadian mahasiswa organisator maka akan semakin tinggi pula perilaku asertifnya. Begitu pula semakin introvert mahasiswa organisator maka akan semakin rendah perilaku asertifnya. Jadi hipotesis yang diajukan yaitu ada perbedaan perilaku asertif yang signifikan antara tipe kepribadian ekstrovert dan introvert pada mahasiswa organisator UIN Antasari Banjarmasin diterima.

Dalam penelitian ini, mahasiswa organisator UIN Antasari Banjarmasin yang memiliki kecenderungan tipe kepribadian ekstrovert menunjukkan lebih berperilaku asertif jika dibandingkan dengan mahasiswa organisator yang memiliki kecenderungan tipe kepribadian introvet. Hal ini diketahui dengan melihat nilai rata-rata (mean diference) sebesar 7,296 dan perbedaan berkisar antara 3,042 sampai 11,550 (lihat lower dan upper), karena nilai rerata berbentuk positif, berarti kelompok pertama (kepribadian ekstrovert) memiliki mean lebih besar dari kelompok kedua (kepribadian introvert) yang berarti kecenderungan kepribadian ekstrovert memiliki perilaku asertif yang lebih tinggi dibanding kecenderungan kepribadian introvert.

Sejalan dengan penelitian Adnan dan Hidayati, individu dengan tipe kepribadian ekstrovert yang mengikuti organisai akan lebih mudah untuk berperilaku asertif karena memiliki kecenderungan yakni senantiasa mempunyai fokus pada dunia luar, menyampaikan keinginan dan dapat bersosialisai secara ramah dan aktif dengan individu lainnya(Adnan \& Hidayati, 2018). Saat individu mengikuti kegiatan organisasi tentunya membutuhkan perilakuperilaku yang berhubungan dengan orang lain, seperti mengungkapkan pendapat, mengungkapkan pujian, rasa terima kasih, menolak permintaan, dan sebagainya. 
Eysenck berpendapat dalam Asterina mengenai individu dengan kepribadian ekstrovert adalah individu yang mencari stimuli sehingga ia dapat lebih banyak beragrumen dikarenakan karena argumen merupakan sumber stimuli sehingga individu dengan kepribadian introvert lebih memilih untuk menghindari argumen dan stimuli sehingga orang dengan tipe kepribadian introvert kadang kala berperilaku kurang asertif (Asterina, 2012). Dari beberapa paparan hasil analisis data dan teori diatas semakin membuktikan bahwa mahasiswa yang memiliki kepribadian ekstrovert lebih berperilaku asertif dibandingkan dengan mahasiswa organisator dengan tipe kepribadian introvert.

Penelitian ini memiliki keterbatasan yaitu saat penyebaran angket peneliti tidak membubuhkan usia untuk diisi oleh para responden, keterbatasan referensi terkait perilau asertif yang membuat peneliti mengalami kesulitan untuk mencari literatur yang relevan dan penelitian ini hanya berfokus untuk meneliti perilaku asertif yang ada pada mahasiswa organisator sehingga tidak dapat melihat perilaku asertif yang bukan mahasiswa organisator.

\section{Kesimpulan}

Dari pemaparan diatas dapat disimpulkan bahwa mahasiswa organisator yang memiliki kecenderungan kepribadian ekstrovert mempunyai perilaku asertif yang lebih tinggi dibandingkan dengan mahasiswa organisator dengan kecenderungan kepribadian introvert. Dimana kategori perilaku asertif pada mahasiswa organisator UIN Antasari Banjarmasin berada pada persentase yang rendah sebesar 53,3\%. Selanjutnya kecenderungan perilaku asertif pada mahasiswa organisator pada aspek bertindak menurut kepentingan sendiri sebesar 31,2\%. Fakta lain yang ditemukan dalam penelitian ini, tipe kepribadian terhadap perilaku asertif juga berpengaruh sebesar 16,9\% dari 100\%. Fakta yang ditemukan bahwa ada faktor lain sebesar $83,1 \%$ yang dapat mempengaruhi individu untuk berperilaku asertif khususnya dalam berorganisasi. Hasil analisis data sebanyak 33 responden atau 55\% memiliki kecenderungan kepribadian ekstrovert, selanjutnya sebanyak $45 \%$ atau 27 responden memiliki kecenderungan kepribadian introvert.

\section{Saran}

Untuk peneliti selanjutnya yang ingin meneliti mengenai perilaku asertif diharapkan untuk memperluas sampel penelitian serta meneliti faktor-faktor lain yang dapat mempengaruhi 
seseorang dalam berperilaku asertif, seperti membandingkan mahasiswa yang berorganisasi dan tidak berorganisasi, jenis kelamin, usia, budaya, dan pendidikan serta dapat meninjau dari teori kepribadian yang berbeda. Selanjutnya jika dilihat dari hasil perilaku asertif mahasiswa organisator yang cenderung berada pada kategori rendah, hendaknya pihak kampus memberikan atau mengadakan seminar mengenai pentingnya berperilaku asertif khususnya di lingkungan kampus. Setelah itu saran untuk mahasiswa khususnya yang ikut organisasi hendaknya dapat meningkatkan perilaku asertif dengan turut serta berpartisipasi dalam diskusi agar dapat menyampaikan aspirasinya dengan baik dan lugas. Sehingga dapat meningkatkan kemampuan mahasiswa dalam berperilaku asertif.

\section{Referensi}

Adams, L., \& Lens, E. (1995). Be Your Best. PT Gramedia.

Adnan, A. Z., \& Hidayati, F. (2018). Self-Disclosure Ditinjau dari Tipe Kepribadian dan Self Essteem pada Remaja Pengguna Media Sosial. Jurnal Psikologi Sains dan Profesi, Vol. 2, No. 2.

Alberti, R., \& Emmons, M. (2017). Your Perfect Right Tenth Edition.

Alwisol. (2015). Psikologi Kepribadian Edisi Revisi. UMM Press.

Anfajaya, Muh. A., \& Indrawati, E. S. (2016). Hubungan antara Konsep Diri dengan perilaku Asertif pada Mahasiswa Organisatoris Fakultas Hukum Universitas Diponegoro Semarang. Jurnal Empati, 5.

Asterina, D. A. (2012). Hubungan Tipe Kepribadian Dengan Perilaku Asertif Mahasiswa Fakultas Psikologi UIN Maulana Malik Ibrahim Malang [Skripsi]. Fakultas Psikologi.

Azizah, Y. N. (2016). Perbedaab antara Tipe Kepribadian ekstrovert dan Introvert dengan Tingkat Stres pada Mahasiswa Fakultas Hukum Universitas Muhammadiyah Surakarta [Skripsi]. Fakultas kedokteran.

Azwar, S. (2013). Penyusunan Skala Psikologi. Pustaka Pelajar.

Butar, M. B. (2017). Hubungan Perilaku Asertif dengan Kenakalan Remaja pada Siswa SMP Negeri 6 Kota Tebing Tinggi. Jurnal PGSD FIP UNIMED, Vol. 7, No. 4.

Dewi, K. (2017). Pengaruh Layanan Bimbingan Kelompok dengan Teknik Sosiodrama terhadap Perilaku Asertif Siswa. Indonesian Journal of Guidance and Counseling, Vol. 6, No. 3.

Erlinawati, A. M. (2009). Kecenderungan Perilaku Asertif Pada Remaja Akhir di Yogyakarta [Skripsi]. Fakultas Psikologi. 
Khalisah, S., \& Lubis, R. (2016). Perbedaan Peilaku Asertif ditinjau dari Pola Asuh Orang Tua pada Remaja yang memiliki Clique. Jurnal Diversita, Vol. 2, No. 1.

Kurniawan, M. F. (2016). Perilaku Pro-sosial Ditinjau Dari Tipe Kepribadian Introvert dan Ekstrovert (Studi Pada Mahasiswa Psikologi UNNES) [Skripsi]. Fakultas Ilmu Pendidikan.

Najati, M. U. (2003). Psikologi Dalam Tinjauan Hadits Nabi. Mustaqim.

Puspa, D. (2019). Pengaruh Perilaku Asertif terhadap Perkembangan Sosial Siswa Kelas VII SMP Yayasan Pendidikan Sabilina di Tembung [Skripsi]. Fakultas Ilmu Tarbiyah dan Keguruan.

Ramdhani W, I. (2018). Perbedaan Perilaku Asertif Remaja Laki-laki dan perempuan Korban Bullying dalam Menghadapi Perundungan (Bullying) di SMP Se-Kecamatan Jatisampurna Bekasi (Studi Komparatif Siswa kelas VII SMP Se-Kecamatan Jatisampurna). [Skripsi]. Fakultas Ilmu Pendidikan.

Sugiyono. (2006). Metode Penelitian Administrasi. Penerbit Alfabeta.

Verina, A. I. (2019). Kecenderungan dan Faktor-Faktor yang Memengaruhi Perilaku Asertif pada Mahasiswa yang Aktif Berorganisasi di Kampus [Skripsi]. Fakultas Psikologi.

Wahidiyanti, E. (2015). Hubungan Keaktifan Mahasiswa dalam Mengikuti Organisasi Kemahasiswaan berdasarkan Jenis Kelamin Anggota Organisasi HMJ Sosiologidengan Prestasi Akademik (Studi Kasus Pada Mahasiswa Sosiologi Angkatan 2011 dan 2012 Universitas Lampung) [Skripsi]. Fakultas Ilmu Sosial dan Ilmu Politik.

Zainab, S. (2018). Urgensi Perilaku Asertif Bagi Da'i dalam Menyampakan Dakwah [Skri[si]. Fakultas Dakwah dan Komunikasi.

\begin{tabular}{|l|l|l|l|l|}
\hline Submit & Review & Revisi & Diterima & Publis \\
\hline $16-04-21$ & $07-05-21$ dan & 20-05-21 dan & $20-06-2021$ & $04-02-2022$ \\
& $12-06-21$ & $12-06-21$ & & \\
\hline
\end{tabular}

Pahmiah, Mubarak, dan Mahdia Fadhila

Program Studi Psikologi Islam

Fakultas Ushuluddin dan Humaniora

Universitas Islam Negeri Antasari Banjarmasin

Email: miahpahmiah@yahoo.com 